Ostracode Biostratigraphy

of the Yorktown Formation

(upper Miocene and lower

Pliocene) of Virginia

and North Carolina

GEOLOGICALSURVEY PROFESSIONAL PAPER 704

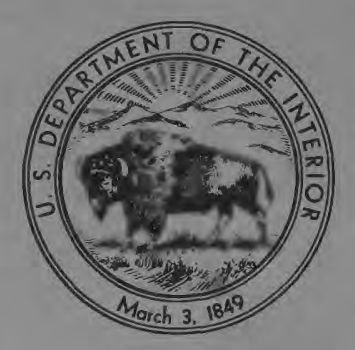




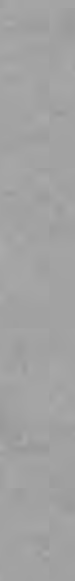




\section{Ostracode Biostratigraphy of the Yorktown Formation (upper Miocene and lower Pliocene) of Virginia and North Carolina}

By JOSEPH E. HAZEL

GEOLOGICAL SURVEY PROFESSIONAL PAPER 704

Three ostracode assemblage zones are proposed for deposits assigned to the Yorktown Formation. The older two zones are considered to be late Miocene in age and the youngest early Pliocene 
UNITED STATES DEPARTMENT OF THE INTERIOR

\author{
GEOLOGICAL SURVEY
}

William T. Pecora, Director

Library of Congress catalog-card No. 76-610127

For sale by the Superintendent of Documents, U.S. Government Printing Office Washington, D.C. 20402 - Price 30 cents (paper cover) 


\section{CONTENTS}

Abstract.
Introduction
Acknowledgments
Previous work.
Ostracode biostratigraphy

\section{ILLUSTRATIONS}

Figure 1. Map showing location of collections. Page

2. Q-mode dendrogram and trellis diagram based on calculation of Dice similarity coefficients

3. Chart showing suggested biostratigraphic position of Yorktown samples used in Q-mode analysis

4. R-mode dendrogram for 80 ostracode species that occur in five or more samples

5. Map showing location of samples containing brackish-water elements

6. Diagram showing general trend through time of the Yorktown transgression and regression $\ldots \ldots$

\section{TABLE}





\section{OSTRACODE BIOSTRATIGRAPHY OF THE YORKTOWN FORMATION (UPPER MIOCENE AND LOWER PLIOCENE) OF VIRGINIA AND NORTH CAROLINA}

By Joseph E. HAzeL

ABSTRACT

The Yorktown Formation of Virginia and North Carolina is divided into three ostracode assemblage zones based on the occurrence of 230 species in 43 samples. The samples were compared in Q-mode using the Dice binary similarity coefficient and cluster analysis. From oldest to youngest, the three zones are the Pterygocythereis inexpectata, Orionina vaughani, and Puriana mesacostalis Zones. The first two are late Miocene in age and the last, which is poorly represented in Virginia, is considered to be early Pliocene in age.

The level of association (R-mode study using the Dice coefficient) between 80 of the more commonly occurring species is shown by means of a dendrogram; values for the biostratigraphic fidelity and constancy of each of these species for each of the zones are given.

A general trend through time from late Miocene to early Pliocene for the Yorktown transgression and regression is suggested, based on the occurrence of brackish-water ostracodes and bivalves, particularly Cyprideis and Corbicula. It is suggested that rapid transgression of the sea occurred during early Yorktown time to a maximum during the time represented by the middle Orionina vaughani Zone. A more or less steady regression of the sea followed during the remainder of Yorktown time.

\section{INTRODUCTION}

The Yorktown Formation (upper Tertiary) of North Carolina and Virginia is a very fossiliferous, lithologically heterogeneous unit with an exposed thickness (natural exposures or open-pit mines) of about 70-120 feet. The sandy clays and clayey sands assigned to the Yorktown crop out discontinuously in a 16,800 -squaremile area between the Rappahannock River in Virginia and the Neuse River in North Carolina (fig. 1). South of the Neuse River, deposits of the same general age as the Yorktown are usually mapped as Duplin Marl.

No microfossil zonation exists for the Yorktown. This report presents the results of a reconnaissance collecting program in conjunction with examination of existing museum collections, the object being to provide a regional ostracode zonation. Localities (fig. 1 ; p. 10) were chosen on the basis of geographic and stratigraphic spread. More detailed collecting will be done in locally complex areas such as the York-James peninsula where the distribution of numerous lithofacies within the Yorktown is being studied (Johnson, 1969; Coch, 1968; Bick and Coch, 1969).

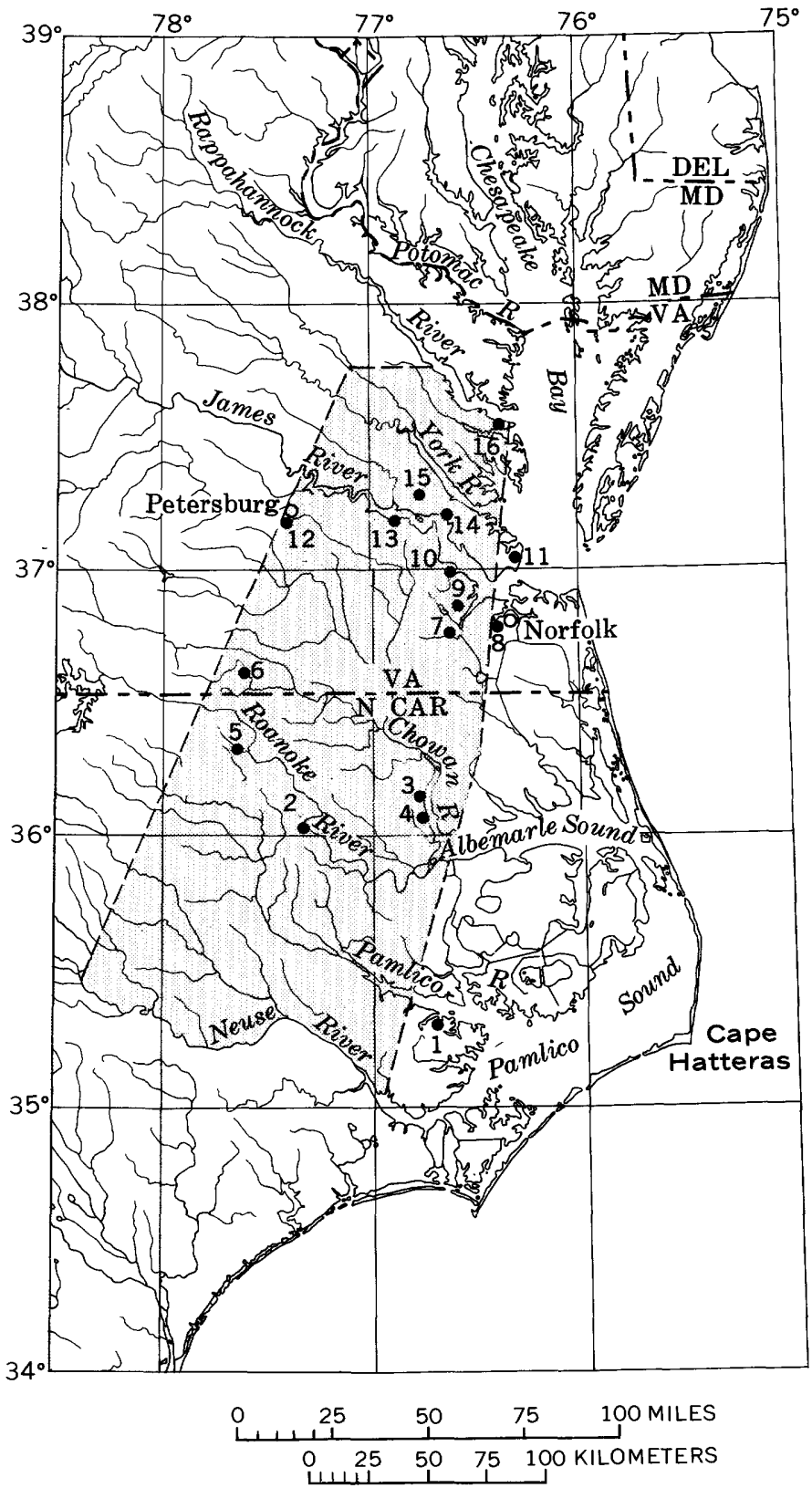

FIgURe 1.--Location of collections; numbers correspond to those in locality list (p. 10). Dashed line encloses area in which Yorktown Formation crops out in natural exposures. 


\section{ACKNOWLEDGMENTS}

I am grateful to T. R. Waller, P. C. Valentine, and Druid Wilson for critically reading the manuscript and making suggestions for its improvement. Warren Blow, T. R. Waller, Druid Wilson, L. W. Ward, and T. G. Gibson made collections available for this study. The Texas Gulf Sulphur Co. allowed me access to exposures in their Lee Creek, N. C., mine. Mr. Blow also provided valuable technical assistance.

The calculations used in this paper were made on the U. S. Geological Survey IBM system $360 / 65$. The program used is coded A243. I thank Paul Zabel and Nancy J. Cotner for their technical help and advice during this phase of the study.

\section{PREVIOUS WORK}

The only extant formal zonation for the Yorktown deposits is that of W. C. Mansfield (in Gardner, 1943) which is based on mollusks collected in the 1920's and 1930's. Mansfield divided the Yorktown of Virginia into two zones. He placed the lower beds of the formation in the Pecten clintonius Zone (or Zone 1) which he said did not exceed 25 feet in thickness. He referred the remainder of the Yorktown of Virginia to the Turritella alticostata Zone (or Zone 2), which he divided into "beds" or "groups" of beds. As Mansfield defined and used them, these are neither lithic nor biostratigraphic units (see discussions by McLean, 1956; Johnson, 1969), and the correlations he proposed for some of the units of Zone 2 are of doubtful validity. Despite this and poor locality data for many of the species listed as indicators of either of the zones, Mansfield's two-zone scheme has been a workable macrofossil zonation for the Yorktown of Virginia.

Although the foraminifers of the Yorktown have been studied (see McLean, 1956, 1966, and references therein), no zonation based on them has been proposed. Ulrich and Bassler (1904), Malkin (1953), Swain (1951), Brown (1958), and McLean $(1957,1966)$ have studied the ostracodes, and only about 50 species occurring in the Yorktown have been reported by these authors. Malkin (1953) suggested a zonation for the Yorktown based on 30 species identified from 12 samples from three localities in the York-James peninsula area. She proposed two zones, a lower Hemicythere schmidtae Zone and an upper Hemicythere conradi Zone. Unfortunately, Malkin's zones are virtually impossible to delineate, partly because of taxonomic advances, but principally because she identified too few species from too few samples and localities.

\section{OSTRACODE BIOSTRATIGRAPHY}

Ostracodes were identified from 46 samples and 16 localities (fig. 1). The Yorktown Formation contains a large ostracode assemblage of 230 species. In 43 of the samples the species diversity was sufficiently high to allow sample comparison using binary similarity coefficients and cluster analysis. A discussion of the application of these techniques to biostratigraphy is in Hazel (1970).

Figure 2 is a Q-mode (samples compared on the basis of their species content) dendrogram (unweighted pairgroup method) and trellis diagram for 43 samples resulting from the calculation of Dice similarity coefficients $2 C / N_{1}+N_{2}$, where $C=$ number of species in common between two samples, and $N_{1}$ and $N_{2}$ are the number of species in the two samples; the similarity values are multiplied by 100 to remove the decimal point. There are three major clusters in the dendrogram, labeled $A, B$, and $C$. One of the samples, 31, clusters late; it will be discussed later. The three major clusters of faunally similar samples are interpreted as representing three ostracode assemblage zones here named from lowest to uppermost, the Pterygocythereis inexpectata Zone (cluster $A$ ), Orionina vaughani Zone (cluster $B$ ), and Puriana mesacostalis Zone (cluster $C$ ).

Correlation of certain samples within major clusters is not obvious from inspection of the dendrogram in figure 2. This is a result of environmental "noise" and species provinciality, because the samples within the clusters are spread over a wide area and may represent different environments. The trellis diagram of figure 2 gives the similarities, in 20-point classes, among all the samples. Analysis of the trellis diagram (as well as the computer printout of the matrix of calculated coefficients of which the trellis diagram is a summary) and of the stratigraphic position of the samples results in the correlations suggested in figure 3 .

Figure 4 is an R-mode (species compared to each other on the basis of the samples in which they occur) dendrogram for 80 of the more commonly occurring Yorktown species. The clusters represent groups of closely associated species. Opposite the endpoints in the dendrogram are numbers indicating the biostratigraphic fidelity (BF) and constancy (C) of that species for each of the proposed zonal units. Constancy is simply the percentage, expressed in tens, of samples from a zonal unit in which a species occurs. Biostratigraphic fidelity is calculated by

$$
\mathrm{BF}_{j, i}=\frac{P i}{\sum_{i=1}^{p} P i} \times 10,
$$

where $j$ is the species $(j=a, b, c \ldots n)$; and $P i$ is the percentage of occurrences in a biostratigraphic unit $i$ $(i=1,2,3 \ldots p)$. The $\mathrm{BF}$ of a species for a particular biostratigraphic unit is therefore calculated by dividing 


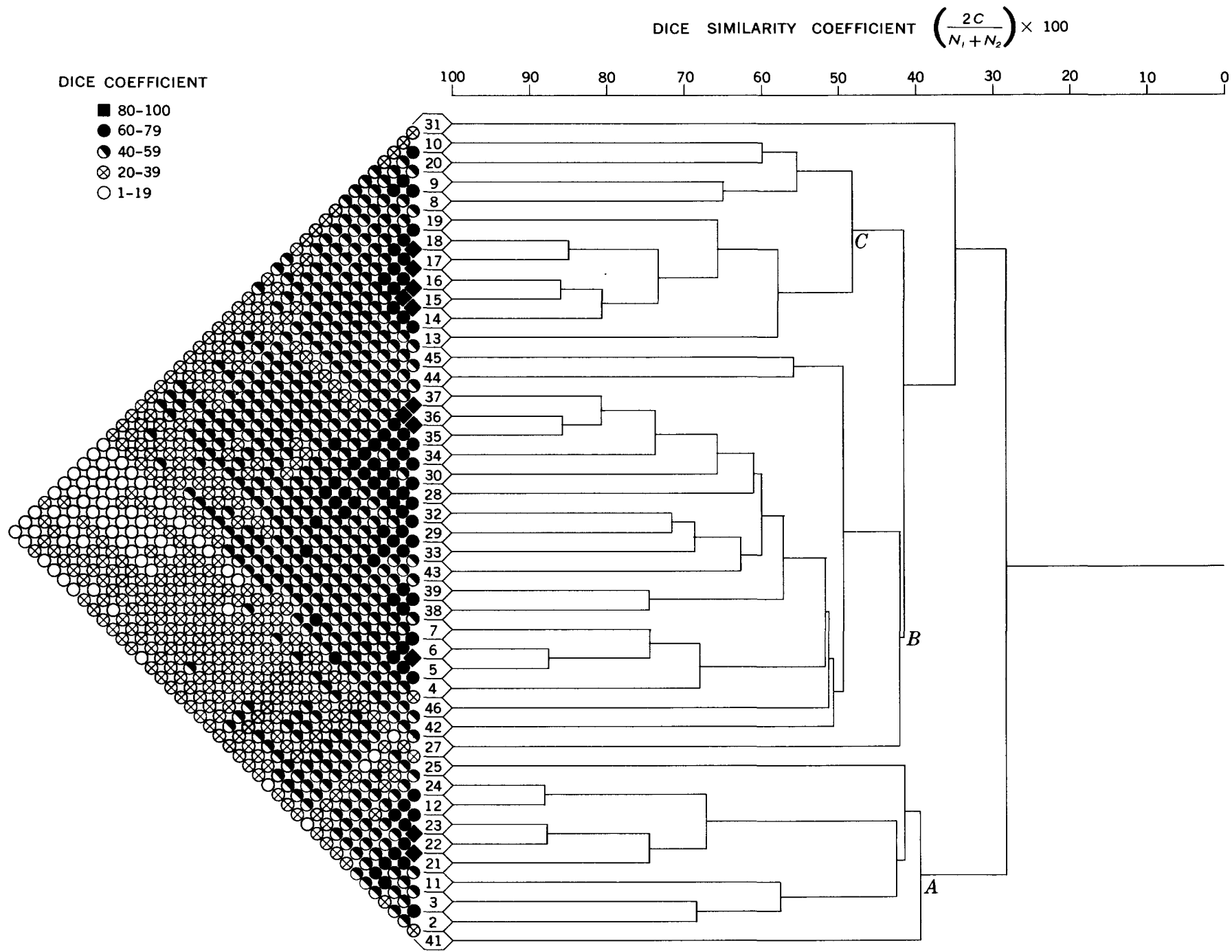

FIGURE 2.-Q-mode (samples compared on the basis of the species content) dendrogram and trellis diagram based on calculation of Dice similarity coefficients for 43 Yorktown samples containing 230 ostracode species. The unweighted pair-group method was used in clustering for the dendrogram. Values in the trellis diagram are given in 20-point classes.

the percentage of occurrences of a species in a biostratigraphic unit by the sum of the percentage of occurrences of that species in all other biostratigraphic units within the limits of the problem. (See Hazel, 1970, for further discussion.) Biostratigraphic fidelity and constancy are expressed in tens to indicate the level of precision of the method and to remove the decimal point. Biostratigraphic fidelity can be considered a quantification of the guide-fossil concept, and the values listed in figure 4 can be used as guides for monothetic biostratigraphic placement of samples. The values for $\mathrm{C}$ and $\mathrm{BF}$ may change as more data accumulate.

A list of the species used in the R-mode analysis is given in table 1 . Representative specimens of the 80 species are deposited in the collections of the U.S. National Museum under Nos. 167376 through 167456. The specimens may be borrowed from the Museum for study.

The assemblage of the Pterygocythereis inexpectata Zone is smaller than those of the two upper zones; 52 species have been identified, but relatively few of these characterize the assemblage. The forms with the highest $\mathrm{BF}$ and $\mathrm{C}$ values for this zone appear in figure 4 in the 61-71 cluster. Species of the 22-31 cluster of figure 4 also occur commonly in the Pterygocythereis inexpectata Zone, but have equal or higher values of $\mathrm{BF}$ for the Orionina vaughani Zone. 

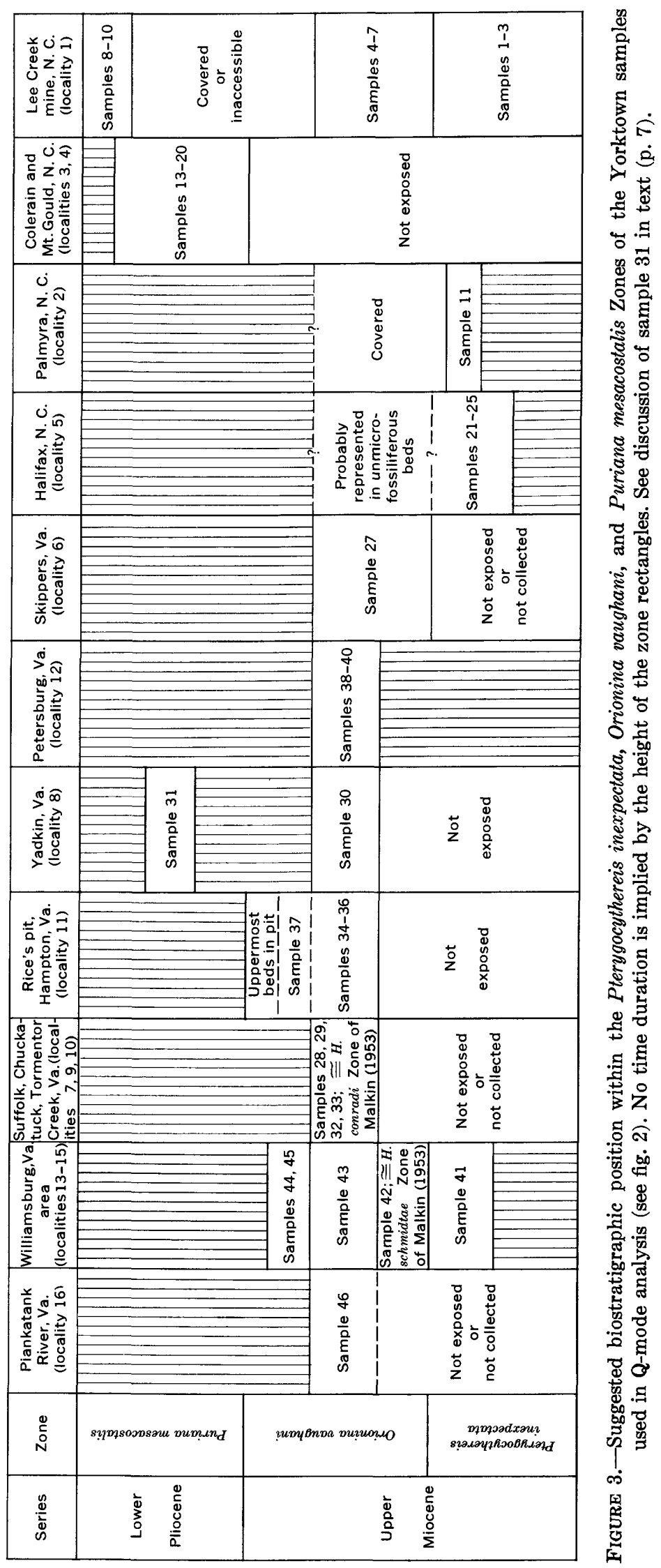


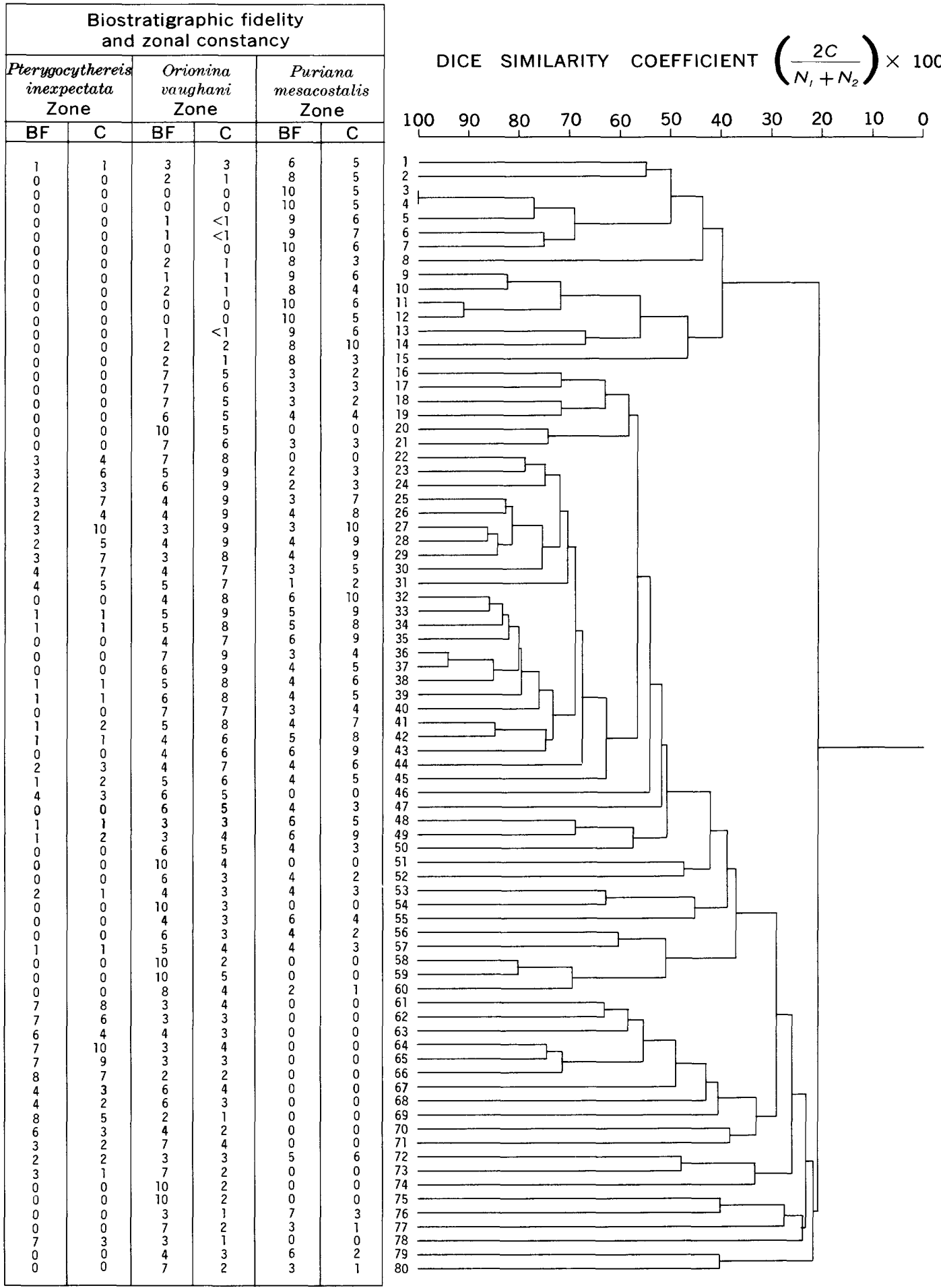

FiguRE 4.-R-mode (species compared with each other on the basis of the samples in which they occur) dendrogram (Dice coefficient; unweighted pair-group method) for the 80 Yorktown ostracode species that occur in five or more samples. The constancy, C, and biostratigraphic fidelity, BF, of each species for each zone are indicated on the left (see text for discussion). The BF and $\mathrm{C}$ values are based on the occurrences within the 43 samples used in Q-mode analysis (fig. 2); sample 31 was not used because it contains specimens reworked from the underlying bed (see text p. 7). The names and occurrences of the 80 species are shown in table 1 . 
TABLE 1.-Occurrence of 84 Yorktown ostracode species that occur in four or more samples

[The species are listed in the order they appear in the R-mode dendrogram (fig. 4). The last four species were not used in the R-mode study]

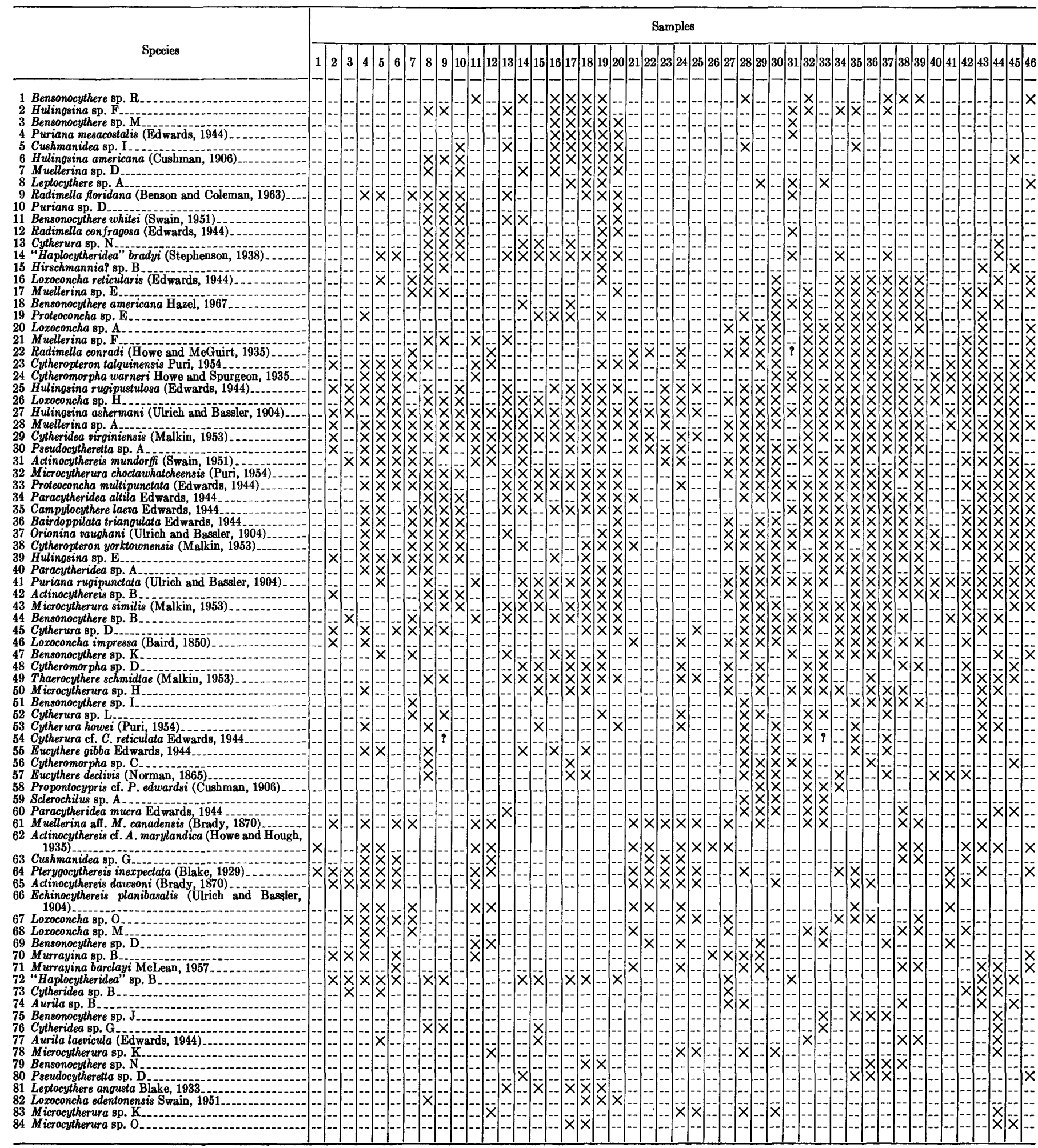


Deposits considered to be in the Pterygocythereis inexpectata Zone include (fig. 3) the lower 10 feet of Yorktown at the Lee Creek open-pit mine on the Pamlico River, N. C. (loc. 1, p. 10) (also see Gibson, 1967); the fossiliferous beds overlying the granite at Halifax, N. C. (loc. 5); at least the lowermost bed of the Yorktown on the Roanoke River near Palmyra Landing, N. C. (loc. 2 ); and the lower beds of the Yorktown on the James River near Mount Pleasant, Va. (loc. 13). The Pterygocythereis inexpectata Zone is approximately equivalent to the Pecten clintonius Zone of Mansfield (in Gardner, 1943). However, some of the beds along the York and James Rivers assigned by Mansfield to the upper part of his Pecten clintonius Zone contain ostracode assemblages referable to the lower part of the Orionina vaughani Zone, for example, the beds assigned by Malkin (1953) to her Hemicythere schmidtae Zone.

Ostracodes are abundant and diverse in the Orionina vaughani Zone; 160 species have been identified from the 21 samples assigned to this zone. The large cluster in figure 4 from species 16 through 60 contains forms which have high $\mathrm{BF}$ and $\mathrm{C}$ values for this zone.

In North Carolina the Orionina vaughani Zone assemblage occurs in the Lee Creek mine from about 13 feet to at least 33 feet above the base of the Yorktown (material from the interval between 33 and $53 \mathrm{ft}$ above the base of the Yorktown could not be collected when the mine was visited in June 1969). All the samples studied from the Yorktown of Virginia except 31 and 41 are assigned to the Orionina vaughani Zone. Malkin's (1953) samples from the area of the type Yorktown can be assigned to the Orionina vaughani Zone on the basis of the BF values for the species she lists.

In Virginia the Orionina vaughani Zone approximates the Turritella alticostata Zone of Mansfield with some important differences. Mansfield (in Gardner, 1943) indicated that Yorktown beds at Suffolk and near Franklin (his Bigg's Farm locality) were the youngest Yorktown in Virginia. He correlated these beds with the Yorktown in the Colerain and Mount Gould areas on the Chowan River in North Carolina. In the present study the subaerially out-cropping beds at Colerain Landing as well as those at Mount Gould Landing are considered younger than any of the Yorktown of Virginia, except for that represented by sample 31. MacNeil (1938) on the basis of the distribution of certain Noetinae (bivalves) also concluded that the Chowan River, N. C., beds are younger than any of the Yorktown of Virginia.

The 1-15 cluster in figure 4 contains species with high $\mathrm{BF}$ and $\mathrm{C}$ values for the Puriana mesacostalis Zone. In addition, the 16-60 cluster contains many species with high $\mathrm{C}$ values for this zone. In the Puriana mesacostalis Zone are placed the beds in the bluffs on the Chowan
River at Mount Gould Landing (loc. 4) and at Colerain Landing (loc. 3), at least the upper 12 feet of the Yorktown at the Lee Creek open-pit mine (fig. 3), and sample 31. Sample 31 was collected in a borrow pit near Yadkin, Va. (loc. 8), from an unconsolidated to indurated 3foot-thick unit of dark-red iron-stained clayey sand containing sparse unstained clayey sand beds. The ironstained unit occurs stratigraphically below the marine Norfolk Formation (Pleistocene) (as used by Oaks and Coch, 1963; Oaks, 1964) and contains hematite nodules, indurated mudballs, much comminuted shell, whole specimens of the bivalve Corbicula densata (Conrad, 1843), and 37 species of Ostracoda. Underlying this unit are exposed at least 10 feet of blue clayey sand packed with broken and whole mollusks (sample 30, placed in the Orionina vaughani Zone). Spencer and Rogers (1969) place the iron-stained bed in the basal Pleistocene and the blue fossiliferous clayey sand in the Yorktown.

The comminuted shell in the iron-stained bed is probably reworked from the underlying blue fossiliferous sand. Several of the ostracode specimens also appear to be reworked. The assemblage is a mixture of species that occur in both the Orionina vaughani and Puriana mesacostalis Zones with species otherwise restricted to either the Orionina vaughani or Puriana mesacostalis Zones. This is reflected in the late clustering of sample 31 in figure 2.

Five species occur in sample 31 that are known only from the Orionina vaughani Zone. Two of these occur commonly in that zone and in the blue fossiliferous beds below the iron-stained bed (sample 30); one of these species is represented in sample 31 by a single specimen and the other by three specimens. The presence of these species in sample 31 probably represents reworking from the beds below. The other three species occur rarely in the Orionina vaughani Zone in assemblages judged to represent environments similar to that of sample 31 (samples 38 and 45, for example) and therefore may very well be part of the natural assemblage of the sample.

Also present in sample 31 are species such as Puriana mesacostalis (Edwards, 1944) (species 4), Bensonocythere sp. M (species 3), and Radimella confragosa (Edwards, 1944) (species 12) which are common in and restricted to the Puriana mesacostalis Zone and younger levels. The samples with which sample 31 has the highest similarity values are those from the Puriana mesacostalis Zone on the Chowan River (samples 16, 17). The ironstained bed is considered part of the Puriana mesacostalis Zone and not of Pleistocene age (so placed by Spencer and Rogers, 1969). This interpretation is corroborated by the presence of Corbicula densata which is not known to occur in deposits as young as Pleistocene 
(Gardner, 1943). The bed is the youngest Yorktown yet found in Virginia.

The nature of the contact between the iron-stained Corbicula-bearing bed and the blue bioclastic beds suggests a disconformity. If the biostratigraphic placement of samples 30 and 31 (fig. 3 ) is correct, the contact represents the upper part of the Orionina vaughani Zone and lower part of the Puriana mesacostalis Zone, suggesting erosion occurred during this time.

As mentioned above, it is this contact that Spencer and Rogers (1969) selected as the Yorktown-Pleistocene contact and presumably mapped in the subsurface of Norfolk County, Va. The northwest-southeast trending flexure which they consider the cause of the thinning of the "Pleistocene" in the Yadkin area may be the structural control for the disconformity within the Yorktown. See also the discussion of structural features by Oaks (1964, p. 70-80).

\section{AGE OF THE YORKTOWN FORMATION}

The Yorktown Formation has traditionally been considered the youngest Miocene unit in the Middle Atlantic Coastal Plain (Cooke and others, 1943). However, virtually no benthonic species which allow correlation with the late Miocene (Tortonian-Messinian) of the type areas in Italy occur in the Yorktown. Diagnostic planktonic foraminifers are rare in the Yorktown because most of the beds represent shallow water deposition under temperate conditions. However, Gibson (1967) reports a late Miocene planktonic foraminiferal assemblage from beds here assigned to the Pterygocythereis inexpectata Zone at the Lee Creek mine in North Carolina. Diagnostic foraminifers from other parts of the Yorktown are not known.

As pointed out above, Mansfield (in Gardner, 1943) correlated the upper part of his Turritella alticostata Zone of Virginia (this zone is approximately equivalent to the Orionina vaughani Zone) with the Yorktown exposed on the Chowan River near Colerain and Mount Gould, N. C. However, because the ostracode assemblages indicate that the latter deposits are clearly younger than those of the Yorktown of Virginia, except for that represented by sample 31, they are placed in the Puriana mesacostalis Zone.

The Puriana mesacostalis Zone is therefore younger than Yorktown deposits traditionally considered late Miocene in age; it is here tentatively considered to be of early Pliocene age. Even this heterodox view of the age of the Yorktown and its correlatives may be conservative. The occurrences of certain mollusks and ostracodes indicate that the Jackson Bluff Formation of Puri and Vernon (1964), containing the Ecphora and Cancellaria Zones, of western Florida is correlative with the upper Yorktown of Virginia (Orionina vaughani Zone). The matrix from inside a bivalved specimen of Dosinia acetabulum (Conrad, 1832) collected from the type locality of the Ecphora Zone at Alum Bluff on the Apalachicola River (the specimen is from bed 4 of Puri and Vernon, 1964, p. 204; USGS 2210) has yielded the following planktonic foraminifers (identified by Ruth Todd, U.S. Geological Survey):

Globigerina bulloides apertura Cushman, 1918

G. dutertrei d'Orbigny, 1839

Globigerinoides quadrilobatus sacculifer (Brady, 1879)

G. quadrilobatus trilobus (Reuss, 1850)

G. ruber (d'Orbigny, 1839)

Globorotalia acostaensis pseudopima Blow, 1967

G. miocenica Palmer, 1945

Sphaeroidinellopsis subdehiscens (Blow, 1959)

Turborotalita quinqueloba (Natland, 1938)

This assemblage suggests that the Ecphora Zone should be assigned to Blow's (1969) planktonic zones N18 or N19. The lower part of N18 is considered by Blow to be upper Miocene (Messinian); upper N18 and N19 are lower Pliocene (Zanclian). Thus, it may be that the upper Miocene-lower Pliocene boundary in the Atlantic and Gulf Coastal Plain eventually will be revised further downward to include in the Pliocene more of the deposits that have been traditionally assigned to the upper Miocene.

\section{PALEOGEOGRAPHY}

The ostracode genera Cyprideis and Perissocytheridea are primarily inhabitants of brackish water (see Sandberg, 1964a, b, Morkhoven, 1963). Also a brackish water inhabitant is the late Miocene-Holocene species Cytheromorpha curta Edwards, 1944. (See Darby, 1965). Modern species of the bivalve Corbicula live in fresh to brackish habitats (Zhadin, 1952, 1965). In upper Miocene and Pliocene deposits of the Atlantic Coastal Plain, this genus is represented by Corbicula densata (Conrad, 1843). Thus, in fossil assemblages the presence of the bivalve Corbicula or of the ostracodes listed above, particularly Cyprideis, indicates reduced salinity or at least proximity to a brackish water environment from which specimens could be transported into shallow marine habitats. Therefore, the presence of such forms as Cyprideis and Corbicula in fossil assemblages indicates nearness to shore.

Specimens of Cyprideis, Perissocytheridea, and $C y$ theromorpha curta occur in seven of the Yorktown samples studied. Corbicula densata occurs with these forms at four of the localities and has been reported from near the fifth locality.

The oldest Yorktown sample containing Cyprideis is No. 23 from Halifax, N. C. (loc. 5). Here the Yorktown overlies granitic basement, and sample 23 was collected 
about 4 feet above the base of the Yorktown. There is about 40 feet of Yorktown exposed at locality 5, but only in the lower few feet are microfossils preserved.

Two species of Cyprideis occur in sample 38 from Lieutenant Run at Petersburg, Va. (loc. 12). Corbicula densata was originally described from Petersburg by Conrad (1843), but the exact locality is unknown.

Cyprideis, Perissocytheridea, Cytheromorpha curta, and Corbicula densata occur in sample 44 at Williamsburg (loc. 15).

Cyprideis, Cytheromorpha curta, and Corbicula densata occur together in the iron-stained bed in the borrow pit near Yadkin, Va. (sample 31 at loc. 8).

Sample 19 at locality 4 on the Chowan River contains Cyprideis; Corbicula densata was found in the same bed.

Cyprideis is present in sample 10 from the uppermost fossiliferous beds of the Yorktown at the Lee Creek mine; Corbicula densata occurs here also.

The geographic positions of the Cyprideis-Corbiculabearing samples are shown in figure 5 . Their biostratigraphic positions are indicated in figure 3. These Cyprideis-Corbicula points are interpreted to represent approximate positions of the shoreline of the Yorktown sea.

Figure 6 shows the postulated general regional trend of the Yorktown transgression and regression. The Cyprideis-Corbicula points are plotted against the biostratigraphy (fig. 3) and the distance normal to the inferred depositional strike of about N. $20^{\circ}-25^{\circ}$ E., based on the azimuth of the inner edge of the outcrop belt. Positions of samples from Yorktown beds that immediately overlie older formations are also plotted; these are useful in delineating the pattern of transgression. The plane of figure 6 is normal to the inferred depositional strike.

The basal 1 foot of the Yorktown at the Lee Creek mine (loc. 1) contains quartz pebbles and cobbles, phosphate blocks, and cetacean bones. As Gibson (1967) points out, this bed represents a basal transgressive conglomerate. Placopecten clintonius and Pterygocythereis inexpectata are found in this bed of the Yorktown. This is the farthest downdip that the base of the Yorktown can be seen in outcrop; the contact with the underlying Pungo River Formation (middle Miocene) is about 100 feet below present sea level.

A Yorktown bed of middle Pterygocythereis inexpectata Zone age overlies the Cretaceous near Palmyra Landing, N. C. (loc. 2), at about 20 feet above sea level. At Halifax, N. C. (loc. 5), 50 feet above sea level, a bed considered the same age as that near Palmyra Landing overlies Paleozoic(?) granite. Cyprideis occurs in sample 23 about 4.0 feet above the granite. The shoreline was probably never very far west of this area during the

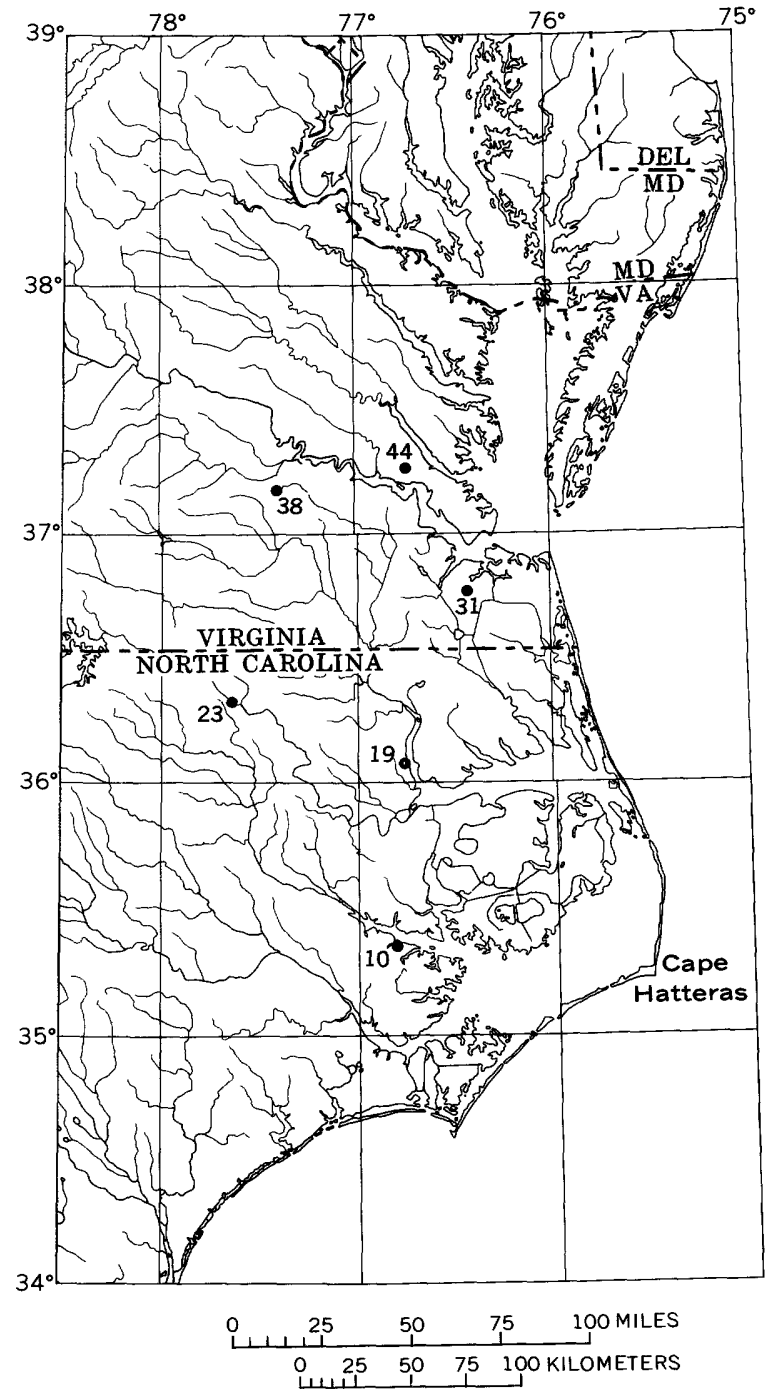

FIGURE 5.-Location of samples containing brackish-water elements, particularly Cyprideis (all samples indicated) and Corbicula (samples 10, 19, 31, 44). It is inferred that the shoreline of the Yorktown sea was very near these localities when the deposits represented by these samples were laid down.

time characterized by the Pterygocythereis inexpectata Zone.

At Petersburg, Va., beds of the middle Orionina vaughani Zone overlie St. Marys Formation and contain species of Cyprideis. The shoreline was no doubt nearby to the west. The maximum Yorktown transgression was during the time of the middle Orionina vaughani Zone, probably at about the time represented by the middle part of the Yorktown exposure at Petersburg. The Yorktown beds at Petersburg are about 100 feet above sea level.

The Yorktown at the Trego Quarry (loc. 6) overlies granite at about 100 feet above sea level. The only sample yet processed from this locality may also be from the 


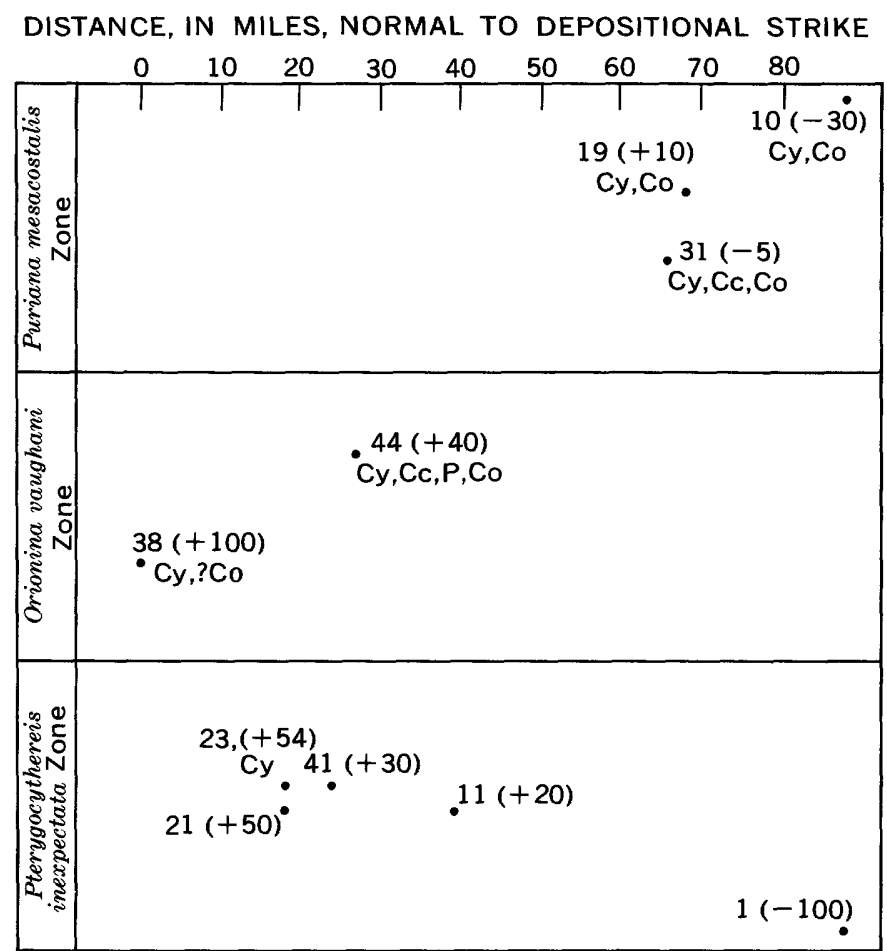

FiguRE 6.-General trend through time of the Yorktown transgression and regression. The plane of the figure is normal to the inferred general depositional strike of N. $20^{\circ}-25^{\circ}$ E. Samples $(10,19,31,44,38,23)$ containing brackish water ostracodes and Corbicula are plotted against the distance between the samples normal to the depositional strike and their biostratigraphic position (fig. 3). Also plotted are samples $(1,11,21,41)$ from Yorktown beds that immediately overlie older formations. The numbers within the parentheses indicate feet above or below present sea level. The abbreviations $\mathrm{Cy}, \mathrm{Co}, \mathrm{P}$, and $\mathrm{Cc}$ stand for Cyprideis, Corbicula, Perissocytheridea, and Cytheromorpha curta (Edwards, 1944), respectively.

middle Orionina vaughani Zone. However, it clusters late (see fig. 2), and its exact position within the zone is equivocal.

Cyprideis-Corbicula-bearing beds marking the regression of the Yorktown sea are present at Williamsburg, Va. (loc. 15), Yadkin, Va. (loc. 8), Mount Gould Landing, N. C. (loc. 4), and the Lee Creek mine (loc. 1). The Williamsburg sample represents the Orionina vaughani Zone; the last three samples represent the Puriana mesacostalis Zone.

The disconformity within the Yorktown at Yadkin, Va., (see p. 8) indicates that at least locally the sea readvanced over an eroded middle Yorktown surface during early Pliocene time.

\section{LOCALITIES}

Locality 1.-Open-pit phosphate mine of the Texas Gulf Sulphur Co. on south shore Pamlico River at mouth of Lee Creek near Aurora, Beaufort County, N. C. (see Gibson, 1967). The following section was collected in the southwestern part of the pit in June 1968.
Unit and description

Thickness
$($ feet $)$

Pleistocene:

10. Buff crossbedded sand $\ldots . .10 .0$

Yorktown Formation:

9. Blue clayey sand, weathered; no macrofossils; microfossil sample barren

8. Blue clayey sand; macrofossils very common; Corbicula densata present in upper part; sample 8 (USGS 24886) in lower $1.0 \mathrm{ft}$, sample 9 (USGS 24887) taken $7.0 \mathrm{ft}$ above base, sample 10 (USGS 24888) in upper $0.5 \mathrm{ft}$ of unit . .

7. Covered or otherwise inaccessible

6. Bluish-gray clayey sand; Turritella molds and casts in lower $6 \mathrm{ft}$; sample 7 (USGS 24885) collected $10.0 \mathrm{ft}$ above base; barren microfossil samples collected $1.0 \mathrm{ft}$ and $5.5 \mathrm{ft}$ above base. . -

5. Blue clayey sand, indurated; many Turritella....

4. Blue clayey sand; Pecten and Turritella; contact with underlying unit irregular; sample 6 (USGS 24884)

3. Blue clayey sand; phosphate and quartz pebbles in lower part; macrofossils present; burrows in upper 1.0-2.0 ft; sample 5 (USGS 24883) in upper $0.5 \mathrm{ft}$ between burrows; sample 4 (USGS 24882) collected $12.0 \mathrm{ft}$ above base; sample 3 (USGS 24881) $7.0 \mathrm{ft}$ above base; sample 2

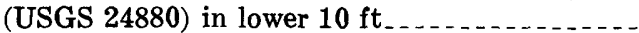

2. Blue clayey sand; phosphate pebbles and quartz cobbles and pebbles; bone; macrofossils, including Placopecten clintonius and Mercenaria; sample 1 (USGS 24879) Pungo River Formation:

1. Phosphatic sands and diatomaceous clay

Total exposed

11.0

23.0

13.0

3.0

Locality 2.-Bluff on right bank of Roanoke River about 1.25 miles below the landing 1.0 mile east of Palmyra, Halifax County, N. C. Sample 11 (USGS 24889) from blue clayey sand with Pecten in basal 1.0 foot of the Yorktown Formation where it overlies a 3-foot indurated sand containing fossil logs in the upper part. Collected by T. G. Gibson and Charles Buddenhagen, November 1965.

Locality 3.--Landing at Colerain, Bertie County, N. C. About 16 feet of Yorktown is exposed in bluffs 100-200 yards south of Colerain Beach Club, right (west) bank of Chowan River. In addition, in June 1969 a spoil pile of fossiliferous sediment (unit 1 below) was present at a Mr. White's cabin. This material was collected by $\mathrm{Mr}$. White from the river bottom some distance offshore at low spring tide after several days of offshore winds; it is not known how far stratigraphically this is below the base of the subaerial outcrop.

Unit and description Thickness
(feet)

Pleistocene:

7. Sand, crossbedded

Yorktown Formation:

6. Clayey sand; weathered buff; macrofossils present; Corbicula densata and Mercenaria present.....-

5. Clayey sand; weathered buff in upper part, mottled in lower part; Pecten and Mercenaria present; sample 15 (USGS 24892) taken $4 \mathrm{ft}$ above base .

4. Greenish blue clayey sand; macrofossils present; sample 14 (USGS 24891) .............
6.0 
Unit and description

3. Greenish-blue clayey sand; macrofossils very common; Glycymeris and Pecten common; bed is at water level; sample 13 (USGS 24890)

2. Normally below water level.........

1. Greenish-blue clayey sand; macrofossils very common; spoil collected from river bottom (see above); sample 12 (USGS 24911)

Total exposed
Thickness
$($ feet $)$

1.0

?

?
39.5

Locality 4.--One-half mile below landing at Mount Gould, Bertie County, N. C.; bluffs on right (west) bank of Chowan River.

Unit and description

Pleistocene:

4. Sand, crossbedded

Yorktown Formation:

3. Gray to buff clayey sand; shell fragments . . . . . .

2. Buff, clayey sand, slightly weathered; macrofossils very common; Pecten, Glycymeris, Corbicula densata, corals; sample 20 (USGS 24897) (from upper $1.0 \mathrm{ft}$; sample 19 (USGS 24896) $3.0 \mathrm{ft}$ above base; sample 18 (USGS 24895) $1.5 \mathrm{ft}$ above base.

1. Green to buff mottled clayey sand; scattered shell fragments; sample 17 (USGS 24894) in upper $1.0 \mathrm{ft}$; sample 16 (USGS 24893) in lower $1.0 \mathrm{ft}$.

Total exposed

Locality 5.-Banks of a northward flowing tributary to Quankey Creek, north side of North Carolina route 5610.5 mile west of railroad crossing over route 561 in Halifax, Halifax County, N. C.

Unit and description

$\underset{\text { Thickness }}{\text { (feet) }}$

Pleistocene:

13. Sand

Yorktown Formation:

12. Gray, clayey sand, unfossiliferous

11. Greenish-gray clayey sand; casts and molds of aragonitic mollusks; scattered oysters and pectenids; elongated concretions in lower $2.0 \mathrm{ft}$; microsamples barren . .....................

10. Clayey sand; indurated; macrofossils present; forms waterfall

9. Greenish-gray clayey sand; scattered macrofossils; sample 26 (USGS 24903) $5.0 \mathrm{ft}$ above base.

8. Blue clayey sand; macrofossils very common; sample 25 (USGS 24902)

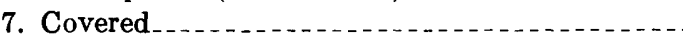

6. Blue clayey sand; macrofossils very common; sample 24 (USGS 24901)

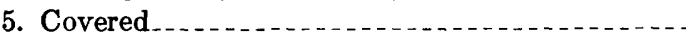

4. Blue clayey sand; macrofossils very common; sample 23 (USGS 24900) ...............

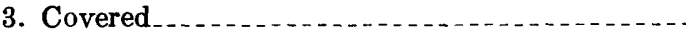

2. Buff clayey sand; macrofossils very common; sample 22 (USGS 24899) in upper $1.0 \mathrm{ft}$ and sample 21 (USGS 24898) in basal $0.5 \mathrm{ft}_{\ldots} \ldots \ldots$

Paleozoic (?):

1. Buff granite

Total exposed

1.0

\section{0

Locality 6.-Trego Stone Corporation quarry, 2.0 miles west of Skippers, Greenville County, Va. Sample 27 (USGS 24830) from upper 1.0 foot of 7.0-foot-thick outcrop of clayey sand with macrofossils, west side of road into quarry. Sample collected by Druid Wilson and Warren Blow.

Locality 7.-Bluff on right (south) bank of Nansemond River, 0.5 mile downstream from Virginia Routes 10 and 32 bridge, about 500 feet northwest of cemetery, city of Suffolk, Va.; about 13 feet of Yorktown exposed near south end of outcrop. Sample 28 (USGS 24811) from greenish-blue clayey sand in lower 0.5 foot of exposure; sample 29 (USGS 24814) from buff clayey sand about 11.5 feet above beach. Samples collected by Richard H. Bailey and Warren Blow.

Locality 8.-Borrow pits 0.5 mile southwest of Yadkin, Virginia, and 0.3 mile south of Norfolk and Western Railroad near intersection of Portsmouth Ditch and powerlines; U.S. Geological Survey Norfolk South 71/2-minute quadrangle map, 1965; lat. $36^{\circ} 45^{\prime} 30^{\prime \prime}$ N., long. $76^{\circ} 22^{\prime} 00^{\prime \prime} \mathrm{W}$. Section measured in cut between north and south pits and in north pit.

Unit and description
(feet)

(?) Sand Bridge Formation (of Oaks and Coch, 1963; Oaks, 1964):

4. Sand, crossbedded; clay and peat interbeds .... 4.0

Norfolk Formation (of Oaks and Coch, 1963; Oaks, 1964):

3. Gray clayey sand; macrofossils present; ironcemented concretions and cobbles in lower part; bed with many Ensis in upper part......... Yorktown Formation:

2. Red clayey sand; variably iron cemented; hematite nodules and indurated mudballs present; many worn broken shells; well-preserved bivalved specimens of Corbicula densata; contact with underlying unit irregular; sample 31 (USGS 24905)

1. Blue clayey sand; macrofossils very common, unit packed with broken and whole mollusk shells; sample 30 (USGS 24904) in upper $4.0 \mathrm{ft}$.......

Total exposed

Locality 9.-Lone Star Cement Co. open-pit mine, 0.5 mile north of Chuckatuck, Nansemond County, Va. Sample 32 (USGS 24622) collected from very fossiliferous clayey sand 12.0 feet below present land surface and 2.5 feet below Pleistocene, west wall, 150 yards from northwest corner (in December 1967) of pit. Collected by Warren Blow.

Locality 10.-Vertical 9.0 to $\mathbf{1 0 . 0}$ foot exposure of Yorktown Formation overlain by Pleistocene on south bank of ravine ąpproximately 0.45 mile northwest of Tormentor Creek; 150 feet east of smaller of two abandoned Lone Star Cement Co. pits and 0.2 mile south of Virginia Route 673, Isle of Wight County, Va.; U.S. Geological Survey Mulberry Island 71/2-minute quadrangle map, 1965. Sample 33 (USGS 24823) collected 0.5 feet below top of Yorktown in brown sandy shell hash. Section measured and collected by Brian Dyer and Warren Blow.

2.0 Locality 11.-Pit belonging to Mr. William Rice, just north of 2.0 intersection of Fox Hill and Harris Creek Roads, Hampton City, Va.; U.S. Geological Survey Hampton $71 / 2$-minute quadrangle map, 1965. Section measured and collected by Warren Blow, Brian Dyer, and T. R. Waller.

Unit and description

Thickness

Pleistocene:

Sand and gravel 
Unit and description

Yorktown Formation:

Buff to gray clayey sand; becoming more clayey and less fossiliferous toward bottom of pit; concentration of Ensis 1.5-2.5 ft below top; sample 37 (USGS 24805) from matrix inside delphinapterid whale skull collected just below Ensis bed; sample 36 (USGS 24907) about $7.0 \mathrm{ft}$ below top; sample 35 (USGS 24906) about $15.0 \mathrm{ft}$ below top; sample 34 (USGS 24810) from matrix inside Echinocardium about $30.0 \mathrm{ft}$ below top and $4.5 \mathrm{ft}$ above bottom of pit.

Total exposed

Locality 12.-Banks of Lieutenant Run, a northeast-to northflowing tributary to the Appomattox River, in southern Petersburg, Va.; fossiliferous beds are east of the railroad crossing over Lieutenant Run and east and north of West Clara Drive, immediately behind (north) of houses on Marshall Court and Field Court.

Unit and description

Yorktown Formation:

4. Blue clay; casts and molds of mollusks, including Yoldia; microfossil sample barren..........

3. Blue clayey sand with scattered blebs of clay (possibly cross sections of burrows)

2. Gray clayey sand; macrofossils very common; more clay toward top; Panopea in living position; sample 40 (USGS 24910) in very clayey sand in upper $1.0 \mathrm{ft}$ of unit; sample 39 (USGS 24909 ) collected $6.0 \mathrm{ft}$ above base; sample 38 (USGS 24908) collected $1.5 \mathrm{ft}$ above base; contact with underlying unit irregular, with sediment of this unit filling burrows of underlying unit

St. Marys Formation:

1. Greenish-gray clayey sand grading downward to greenish-gray sandy clay; scattered macrofossils in upper $6.0 \mathrm{ft}$ (1)

Total exposed $+19.5$

Locality 13.-Right (south) bank of James River, first cliff exposure east of first low-lying point of land 1800 feet west of the colonial home on the Mount Pleasant Estate; 2.7 miles west of Jamestown, Va., lat. $37^{\circ} 12^{\prime} 20^{\prime \prime}$ N., long., $76^{\circ} 49^{\prime} 50^{\prime \prime}$ W. U.S. Geological Survey Surry 71/2-minute quadrangle map, 1965; sample 41 (USGS 24717) from buff clayey sand about 26 feet above beach in lower Yorktown just above bed of Isognomen in St. Marys Formation. Sample collected by Warren Blow.

Locality 14.--Left (north) bank of James River at Camp Wallace Military Reservation, James City County, Va.; see U.S. Geological Survey Hog Island $71 / 2$-minute quadrangle map, 1965. The sample (42, USGS 24912) from this locality was from a slightly glauconitic gray clayey sand matrix adhering to mollusks in the S. F. Blake collection of the U.S. National Museum. The exact stratigraphic and geographic location are unknown; the lithology is similar to that of the lower beds of the Yorktown at nearby Carters Grove described by Malkin (1953, p. 763).

Locality 15.-Campus of the College of William and Mary, Williamsburg, Va.; outcrop is at southeastern face of small knoll in 15.0-foot-deep gully about 50.0 feet north of road which is normal to and directly behind center of west wall of Cary Stadium. Sample 45 (USGS 24819) from upper 1.0 foot of Yorktown in buff to orange fossiliferous coarse sand below contact with Pleistocene(?) sand with pebbles and cobbles; sample 44 (USGS 24820) of same lithology from 2.0-3.0 feet below top of Yorktown. Corbicula densata and Rangia are present in the interval from which samples 45 and 44 were collected. Sample 43 (USGS 24821) collected 4.5 feet below sample 44 in fossiliferous brownish-gray clayey sand. Collections made by Richard $\mathrm{H}$. Bailey and Warren Blow.

Locality 16.-Left (north) bank of Piankatank River 0.25 mile above mouth of Cores Creek, Middlesex County, Va. U.S. Geological Survey Wilton and Deltaville 71/2-minute quadrangle maps, 1964. Section measured and collected by L. W. Ward.

Unit and description

Thickness
$($ feet $)$

Pleistocene:

3. Sand, mostly covered

10.0 Yorktown Formation

2. Sandy coquina, partly indurated; shells broken; sample 46 (USGS 24801) . . . . . . . . . . .

1. Sand; macrofossils very common .............

Total exposed

\section{REFERENCES}

Bick, K. F., and Coch, N. K., 1969, Geology of the Williamsburg, Hog Island, and Bacons Castle quadrangles, Virginia: Virginia Div. Mineral Resources Rept. Inv. 18, 28 p.

Blow, W. H., 1969, Late middle Eocene to Recent planktonic foraminiferal biostratigraphy, in Internat. Planktonic Conf. Microfossils, 1st, Geneva, 1967, Proceedings: Leiden, E. J. Brill and Co., v. 1, p. 199-422.

Brown, P. M., 1958, Well logs from the Coastal Plain of North Carolina: North Carolina Div. Mineral Resources Bull. 72, $68 \mathrm{p}$.

Coch, N. K., 1968, Geology of the Benns Church, Smithfield, Windsor, and Chuckatuck quadrangles, Virginia: Virginia Div. Mineral Resources Rept. Inv. 17, 40 p.

Conrad, T. A., 1843, Descriptions of nineteen species of Tertiary fossils of Virginia and North Carolina: Acad. Nat. Sci. Philadelphia Proc., vol. 1, p. 323-329 [1844].

Cooke, C. W., Gardner, Julia, and Woodring, W. P., 1943, Correlation of the Cenozoic formations of the Atlantic and Gulf Coastal Plain and the Caribbean region [chart no. 12]: Geol. Soc. America Bull., v. 54, no. 11, p. 1713-1723.

Darby, D. G., 1965, Ecology and taxonomy of Ostracoda in the vicinity of Sapelo Island, Georgia, Rept. 2 in Kesling, R. V., and others, Four reports of ostracod investigations: Ann Arbor, Mich., Univ. Michigan Press, p. 57-136.

Gardner, Julia, 1943, Mollusca from the Miocene and lower Pliocene of Virginia and North Carolina: U.S. Geol. Survey Prof. Paper 199-A, 178 p.

Gibson, T. G., 1967, Stratigraphy and paleoenvironment of the phosphatic Miocene strata of North Carolina: Geol. Soc. America Bull., v. 78, no. 5, p. 631-650.

Hazel, J. E., 1970, Binary coefficients and clustering in biostratigraphy: Geol. Soc. America Bull., v. 81, no.11, p. 3237-3252.

Johnson, G. H., 1969, Guidebook to the geology of the YorkJames Peninsula and south bank of the James River: College of William and Mary Dept. Geology Guidebook no. 1, prepared for Tenth Annual Field Conference of the Atlantic Coastal Plain Geol. Assoc., 33 p. 
MacNeil, F. S., 1938, Species and genera of Tertiary Noetinae: U.S. Geol. Survey Prof. Paper 189-A, 50 p.

McLean, J. D., 1956, The Foraminifera of the Yorktown formation in the York-James Peninsula of Virginia, with notes on the associated mollusks: Bull. Am. Paleontology, v. 36, no. 160, p. 255-394.

1957, The Ostracoda of the Yorktown formation in the York-James Peninsula of Virginia: Bull. Am. Paleontology, v. 38 , no. 167 , p. 57-103.

1966, Miocene and Pleistocene Foraminifera and Ostracoda of southeastern Virginia-Pt. 1, Text; Pt. 2, Taxonomy and fossil plates: Virginia Div. Mineral Resources Rept. Inv. 9; Pt. 1, 79 p.; Pt. 2, 123 p.

Malkin, D. S., 1953, Biostratigraphic study of Miocene Ostracoda of New Jersey, Maryland, and Virginia: Jour. Paleontology, v. 27, no. 6, p. 761-799.

Morkhoven, F. P. C., 1963, Post-Paleozoic Ostracoda, their morphology, taxonomy, and economic use: Amsterdam, Elsevier, v. 2 (general descriptions), $478 \mathrm{p}$.

Oaks, R. Q., 1964, Post-Miocene stratigraphy and morphology, Outer Coastal Plain, southeastern Virginia: U.S. Office of Naval Research, Geography Branch, Tech. rept. 5, Task Order NR 388-064, 240 p. (available from Clearinghouse for Federal Scientific and Technical Information, U.S. Dept. Commerce, Springfield, Va. 22151).

Oaks, R. Q., and Coch, N. K., 1963, Pleistocene sea levels, south- eastern Virginia: Science, v. 140, no. 3570, p. 979-983.

Puri, H. S., 1953, Contribution to the study of the Miocene of the Florida panhandle; Part 3, Ostracoda; Florida Geol. Survey Bull. 36, p. 217-345 [1954].

Puri, H. S. and Vernon, R. O., 1964, Summary of the geology of Florida and a guidebook to the classic exposures: Florida Geol. Survey Spec. Pub. No. 5 (revised), 312 p.

Sandberg, Philip, 1964a, The ostracod genus Cyprideis in the Americas: Stockholm Contr. Geology, v. 12, 178 p.

1964b, Notes on some Tertiary and Recent brackish-water Ostracoda: Sta. Zool. Napoli, Pub. v. 33, Supp., p. 496-514. Spencer, R. S., and Rogers, W. S., 1969, The Miocene-Pleistocene unconformity in Norfolk County, Virginia: Virginia Jour. Sci., v. 20 , no. 1 , p. 19-21.

Swain, F. M., 1951, Ostracoda from wells in North Carolina; pt. 1, Cenozoic Ostracoda: U.S. Geol. Survey Prof. Paper 234-A, $58 \mathrm{p}$.

Ulrich, E. O., and Bassler, R. S., 1904, Systematic paleontology, Miocene Arthropoda: Maryland Geol. Survey, Miocene [volume], p. 98-130.

Zhadin, V. I., 1952, Mollyuski presnykh i solonovatykh vod SSSR: Moskva-Leningrad, Izdatl'stvo Akademii Nauk SSSR, 376 p. 1965, Mollusks of fresh and brackish waters of the U.S.S.R.: Israel Program for Scientific Translations, 368 p. (available through the Clearinghouse for Federal Scientific and Technical Information, U.S. Dept. Commerce, Springfield, Va. 22151.) 